\title{
Articles
}

\section{Down Memory Lane ... as LAEL Celebrates its Golden Jubilee}

\author{
Na trilha das recordações ... quando \\ LAEL festeja seu jubileu de ouro
}

\author{
Kanavillil Rajagopalan'
}

\begin{abstract}
In this paper, I attempt to trace the evolution of LAEL over the 50 years of its history, intertwining the narrative with my own personal trajectory since my arrival in Brazil in 1976. The narrative makes no claim to being a step by step account of the different facets of the Programme's history. Rather, the focus is on how its developments through the years mirror the fortunes of the very area of academic pursuit we call Applied Linguistics.
\end{abstract}

Keywords: LAEL; Applied Linguistics; hard-core Linguistics; Edinburgh University; 'Madras snowball'; linguistic imperialism.

1. Universidade Estadual de Campinas - Unicamp. Campinas, São Paulo - Brasil. orcid. org/0000-0003-3877-4936. E-mail: rajan@iel.unicamp.br. 


\section{RESUMO}

Neste texto, procuro traçar a evolução da LAEL ao longo dos 50 anos de sua história, entrelaçando a narrativa com a minha trajetória pessoal desde minha chagada no Brasil em 1976. A narrativa não tem nenhuma pretensão de ser um relato fiel das diferentes facetas do Programa. Ofoco na verdade é sobre como seu desenvolvimento através do tempo espelha as mudanças que ocorreram no campo de pesquisa que chamamos de Linguística Aplicada.

Palavras chave: LAEL; Linguística Aplicada; Linguística 'núcleo duro'; Universidade de Edimburgo; 'Madras snowball'; imperialismo linguístico.

\section{Opening remarks}

Jubilees are invariably occasions of great celebration and indeed, if you pardon the pun, of jubilation (hat tip to the Marvel character 'Jubilation "Jubilee" Lee'). But, when it comes to commemorating the $50^{\text {th }}$ anniversary of the founding of a programme of postgraduate studies, especially in a country like Brazil (which has, as of yet, no solid tradition of university education to boast of - to be sure, nowhere near its glorious analogues in the Old World), the matter has an extra aura to it. The Catholic University of São Paulo, Brazil, has every reason to be proud of hosting a trail-blazing and vibrant programme of postgraduate studies and research in what, at the time of its inauguration, was a relatively unknown field of academic pursuit (in Brazil, as well as, if you come to think of it, elsewhere in the world) called 'Applied Linguistics.' As one pauses to reminisce about LAEL over the past halfcentury, one cannot but be bowled over by the innumerable copy-cat master's and doctoral programmes of similar thrust that have sprung up all over the country since then and continue to do so.

$L A E L$ is, however, not just a pioneering programme of studies; it is also unique in many respects. Although no doubt the oldest of its kind, it has constantly sought to keep itself abreast of the times and never shied away from facing up to new trends and research orientations that have been the hallmark of its five decades of existence. In other words, it has evolved constantly all along, while remaining focused on 
its original intent and commitment, but also keeping attentive to the winds of change that blow from time to time, as they do and should in any genuinely serious academic enterprise.

\section{What there is in a name ...}

The best proof of LAEL's vibrancy and readiness to embrace novelties cropping up every now and then is its own modified appellations, or rather, the two non-trivial nomenclatorial transmutations it has gone through. Not many people may probably know or recall that the abbreviation 'LAEL' originally stood for the Portuguese descriptive name 'Linguística Aplicada ao Ensino de Linguas' (Linguistics Applied to the Teaching of Languages') before being re-baptized 'Linguística Aplicada e Estudos da Linguagem' (Applied Linguistics and the Study of Language). Before anyone comes up with the familiar "So what! A rose by any other name ...," let me hasten to note that, in our age of marketing and the enormous power of branding, no one in their right senses would question the importance of naming. And they shouldn't, especially if you take into consideration some of the major paradigm shifts the vibrant field of Applied Linguistics has been through in the last half-century or something slightly longer than that of its very existence as a field of enquiry in its own right.

But it is also important to remember that, in its early days, the programme was only being faithful to the dreams of its founders who conceived of the new discipline as essentially a bridge between theoretical linguists, who went about their customary business of hard-core theorizing about language, on the one hand, and the ordinary classroom teacher, tucked miles away from the hustle and bustle so characteristic of the corridors of the citadels of academic research, and grinding away at the arduous task of teaching a language, on the other. In so doing, they were only proposing a way out of the dramatic new reality engendered by the science of language, Linguistics, taking a robustly scientific turn, especially in the 1960s and 1970s, and, in the process, distancing itself every step of the way from the needs and aspirations of millions of language users and professionals who had more urgent problems and challenges to attend to. 
In hindsight, it seems reasonable to speculate that the popularity of the then emergent field of Applied Linguistics was aided and abetted by the growing frustration over the way Linguistics itself had chosen to become overly theoretical (well nigh esoteric!) in its ambitions, leaving behind more urgent, earthly concerns - all in the name of its much-sought-after credentials to scientific respectability. It also seems to be the case that a claim that I made some two decades back still holds true to a large extent till to date:

[...] by and large, scientists with a theoretical frame of mind have been given to thinking that genuine scientific work can only be carried out by keeping at bay practical considerations or for that matter consequences of their discoveries on other spheres of human concern. (Rajagopalan, 2003: 399)

The present writer vividly recalls the moment he bumped into Prof. Pit Corder, chair of the Department of Applied Linguistics of University of Edinburgh for the first time way back in early 1970s (roughly the same time as the founding of $L A E L$ - the Department of Applied Linguistics of the University of Edinburgh was founded less than a decade and a half earlier in 1957, the very first of its kind in Britain (cf. https://web.archive.org/web/20121029100702/http:// www.baal.org.uk/dox/history_of_baal.pdf). The occasion was a party to welcome freshmen thrown by the newly inaugurated Applied Linguistics programme of the great Scottish university.

Here I was, in flesh and blood, standing right face to face with the man who had established a name right across the world as the harbinger of a new way of going about things in the approach to practical language issues. Most likely a chill ran down my spine. Such was the fame and the awe-inspiring stature of the man that I had known about well in advance, largely owing to highly laudatory remarks I had heard from linguists I held in high esteem back home in India. Upon introducing myself briefly and letting him know that I had great expectations regarding the course I was just embarking on and that I had just done a Master's degree in Linguistics at the University of Delhi with a thesis in (believe it not!) generative phonology, there came the instant and thoroughly unexpected reaction from the great doyen and savant: "Well, I am sure that will stand you in good stead in your new academic pursuit." I confess I was a bit intrigued (not to 
say, frustrated) as I had gone all the way to Edinburgh hoping I would be able to break some fresh new ground, rather than simply do some follow-on from what I had already done and at best be able to spruce up some of that stuff.

But then it didn't take very long for the idea to dawn upon me that that was exactly what the then burgeoning field of Applied Linguistics thought of itself - some sort of a second fiddler, at the mercy and — and, who would have thought! — at the behest of its more 'scientifically respected' mother-discipline. And many, as it seemed then, were quite happy resigning themselves to their secondary, indeed subservient, role. Corder's (1973) famous description of the applied linguist as "a consumer, or user, not a producer, of theories" would ring in my ears for years to come, cluttering my mind with a growing sense of unease and making me feel, as I dare to admit today, somewhat negatively inclined to pursue the very line of enquiry I had gone all the way to Scotland to take up!

Who on earth and in their right mind likes to be handed the role of a second-fiddler in the orchestra and be told that that is all that they are good for for the rest of their working lives? Why should anyone jump with joy when asked to be a mere bricklayer or even a foreman when they know that nothing prevents them from aspiring to be the engineer in charge of thinking big and contriving things on their own rather than simply executing them at someone else's bidding? Every newcomer to an academic discipline has every right to want to hitch their wagon to a star! After all, Baynham et al.'s 2004 book with the title Applied Linguistics at the Interface wherein they threw down the gauntlet with the bold assertion (along with the uplifting words it is phrased in)

In our view, the applied linguist today is a producer as much as a consumer of theories, subverting the binary distinction between theoretical and applied linguistic knowledge which exercises so many unproductive debates between 'linguists' and 'applied linguists'.

was still some three decades away to make its appearance on the academic scene. 
But many similar attempts to proclaim the autonomy of the area of enquiry called Applied Linguistics often amounted to nothing more than occasional spurts of bravado. The lure of theory, when all is said and done, is an irresistible Siren song, as many practitioners soon discovered, after they had already fallen victim to its charms. As early as the mid 1990s, Van Lier (1994) hit the nail on the head when he complained that "the linguistics in Applied Linguistics has veered off in the direction of theory (in a sense, therefore, has left Applied Linguistics), leaving pedagogy to cope with the practical side of things."

\section{The field in search of an identity}

It should come as a matter of surprise to no one that LAEL too has had its fair share of disciplinary travails over the years. In fact, it battled for quite some time trying to figure out a defining identity for itself, but found itself invariably caught up in the individual proclivities and predilections of the programme teaching staff on whom the responsibility mostly rested. Maria Antonieta Alba Celani, the towering figure (whose name was - and still remains - almost a synonym for LAEL) and deservedly its 'patron saint,' especially after her passing in 2018, who almost single-handedly did all the spadework leading to the creation of the programme, was a teacher of English by training and vocation and was initially, I believe, moved by the idea of making sure that the advances in ongoing research into the workings of language were made available in a more palatable fashion to the growing community of language teachers whose academic upbringing, until then, consisted solely or mainly in concentration on their language proficiency.

Once again, LAEL was only following trends developing in Europe and the United States. In the US, applied linguistics had received its much-needed fillip to burst onto the scene thanks to the sudden postWorld War II surge in demand for language teachers skilled in foreign languages, ready to take on the hitherto-unimagined challenges of a new Super Power that had just emerged from the ashes of that earthshattering event. On the other side of the pond, the British had just woken to the possibility of building a New Empire-the empire of the 
English language - now that they had barely recovered from witnessing the spectacle of the old one whittling down into insignificance before their very eyes.

It is perhaps no exaggeration to venture the hypothesis that, in its early days, Applied Linguistics was just a fancy term for bringing the weight of theoretical Linguistics, already a cynosure of all eyes by then, to bear on the task of spreading English far and wide. And this it did with remarkable success. In Britain, the whole business was taken all too seriously, not the least for the not-to-be-shrugged-off reason that it meant a gold mine for the nation's coffers. In a way, it still does, as the following 'British Council worldwide call for entries to ELTons 2016' that I picked up on a chance surfing on the internet clearly demonstrates:

Anna Searle, Director of English Language at the British Council, said: "English language teaching remains in high demand throughout the world and the UK is a leader in responding to this demand, through innovative approaches to direct and online learning support, and through high quality research and publications which support innovations in English language learning and teaching.

(https://www.britishcouncil.org/contact/press/british-council-worldwidecall-entries-eltons-2016)

But then, with hindsight, it is important also to register that, principally in Britain, behind the apparently altruistic endeavour of making a precious immaterial commodity available to nations right across the world, there was also the not-so-magnanimous agenda of promoting their own brand of English (in its highbrow version, referred to as the Received Pronunciation) and thereby claiming pride of place in matters regarding what is and what is not the right way to speak and to write in the language of Spencer, Shakespeare, Sheridan and so forth.

\section{A personal testimony}

Perhaps a first-hand testimony by someone who has been through the experience of this 'linguistic imperialism' (as it was to be quite 
appropriately named, some two decades later, by Phillipson (1992)) might be in order here. The present writer remembers the day he was asked to take an English language proficiency test to be administered by the department of Applied Linguistics of Edinburgh University in the early 1970s. As it turned out, every overseas student was required to take that test those days at Edinburgh and many other universities in the UK. The rationale, it was said, was to make sure that every foreign student, irrespective of the country of their origin and the language that was spoken in that country, had to prove that they would be capable of following lectures delivered in English (British English, that is) and also submit assignments and term-papers in the language. This, we were told in addition, was a requirement that had been instituted in light of the perception that not every new student from overseas was quite at ease with Standard British English and its high standards, especially as regards its characteristic pronunciation and turns of expression and idiomatic usage.

But the story does not quite end there. The language test that was administered primarily (and exclusively) consisted in the students having to listen to a tape recorder (remember this was a state-of-theart electronic gadget in the 1970s!) monotonously playing sets of 4 words, mostly minimal pairs or similar-sounding lexical items, and the students having to instantaneously tick the right option on a previously distributed sheet with the same words printed. "Kite - Kate - Coat - Quite," the words would belch out of the recording machine, with no provision for a replay, should a confused listener want one. Either you've learnt your vowel chart for RP by heart and at least crammed it in time or you have had it for sure!

The best was yet to come, though. The standing joke of the time that the whole episode left in its wake nevertheless has a rather sad and very painful personal entanglement associated with it. The only one in the batch of some 30-odd students who took the test and who couldn't quite make it was - hold your breath - a US citizen. He was a very nice bloke with whom I had already made friends by then $(\mathrm{He}$ was in fact my room-mate in the youth hostel, a short walk from the campus). He too took the test. Rather, had to. There was no exemption for anyone, unless they held a British passport! (That was the sole criterion used for telling the sheep from the goats!). Then came the 
exam results, and along with it, the ugly surprise. He had got(ten!) it all wrong, especially when it came to getting the vowels of standard British English straight. For instance, /laf/, not/læf/! ;/sıv·ə·lai'zeı·fən/ 'civilisation,' not 'civilization' / sivələ'zāSH(ə)n/ ! Poor Johnny (as I shall call him here)!

The whole episode left Johnny thoroughly grief-stricken and crestfallen. As for me, I was at my wit's end - along with many other common friends and well-wishers. We didn't know where to begin by way of calming him down. I recall accompanying him all the way (had to skip my own classes that morning) to the Educational Recuperation Unit (or something like that, as I vaguely remember) from where he had received a polite note to report a few days later. Upon identifying himself at the reception desk, Johnny was bureaucratically handed a form to fill in. A form containing a number of standard queries such as: "Your name?" No problem with that. "Your nationality?" Another straightforward one. "Your mother-tongue?" There was a long pause. Johnny took a deep breath and started scratching his head. And then he came up with something which he scribbled on the dotted line with all the composure one can muster under the circumstances - something that I will never forget for the rest of my life. Here is what he wrote: "Well, I thought it was English; but now I am not sure anymore"

The episode I have taken pains to recount in some detail in the foregoing four paragraphs does reveal a number of things about the state of applied linguistics itself in its infancy - strange as it might indeed seem at first glimpse! To begin with, the test was a faithful reenactment of the design of language structure that the then still influential school of theoretical linguistics (namely, Structural Linguistics) had envisaged: phonology, morphology, syntax and so on, in a progressive list of compartments of increasing complexity. From phoneme to morpheme and, then, from morpheme to utterance - as Zellig Harris' famous 1946 and 1955 (cf. Harris, 1946, 1955) papers proudly proclaim. Lest anyone should rightly object saying that, by the early 1970s, there already had occurred a major paradigm shift in theoretical linguistics, let me hasten to remind them that the so-called 'Transformational-Generative theory' was only just beginning to make a significant impact roughly around that time in Britain (where the contending Systemic Functional Linguistics approach still reigns supreme till to date). A case in point is 
the fact it was only as late as 1970 that the first edition of John Lyons' blockbuster title Chomsky saw the light of day.

But the episode referred to above also reveals the state of mind that prevailed in Britain among the public at large in those days (one that found fertile ground in academic circles, as well — who would have thought!) which was that there was only one way of speaking English correctly and elegantly and that was the British way. This attitude may partially (though quite significantly) be laid at the door of the simple fact that many of practitioners of Applied Linguistics in its initial phase were English language experts on the payroll of the British Council. Pit Corder himself was a prominent name in this last, as were the late Alan Davies (my course tutor at Edinburgh), Henry Widdowson, Anthony Howatt (also among my Edinburgh teachers) to name just a handful. Even Robert Phillipson (whom I only met personally years later at a conference at Aston University, Birmingham) who revealed himself to be someone sorely disgruntled (or conscience-stricken? - well the jury is still out) - was a British Council employee at the service of Her Majesty!

Coincidence or not, LAEL too has had close ties with the British Council in its early formative years, especially in the last three decades of the 20th century - with the active participation of scholars like Maurice Broughton, Tony Deyes, Mike Scott and John Holmes, alongside other visiting professors such as Derek Bickerton(University of Havaii), Andrew Cohen (Hebrew University of Jerusalem) and Charles Alderson (Lancaster University). They did perform yeoman's service in making LAEL what it is today.

\section{A story mostly untold that I happened to be privy to by sheer happenstance}

I still remember the day I was invited to her office by Dr. Gillian Brown, Edinburgh phonologist and one of my teachers, to - as I soon discovered - sound me out on a most notorious and utterly embarrassing episode in the annals of the British Council in India-known as the 'Madras snowball.' The name refers to a disastrous attempt meticulously choreographed by the British Council to retrain an immensely large 
contingent (the estimates range from 10000 to roughly three times that number) of Indian secondary school English language teachers (all from the southern Indian state of Madras, now renamed Chennai). The whole plan had been hatched in response to a growing apprehension that the people of the then state of Madras were speaking English all too idiosyncratically with that familiar heavy Indian accent and intonation and, in so doing, distancing themselves from the way the British, who originally took the language there, were used to.

To arrest the "wayward drift of the language of Albion from its consecrated native moorings', the plan envisaged intensive phonetic training of local language teachers in the hope of setting off a ripple effect in the rest of the English-speaking community. The Council spent loads of money to see the project through to its completion, transporting expert phoneticians and 'native' English speakers to do the job. And Gillian Brown, my phonology teacher, had been in the forefront.

Here's how Anthony Howard, yet another of my teachers at Edinburgh, described the ill-fated language teaching experiment devised under the auspices of the British Council and touted with great fanfare:

[....] an entirely new approach which seemed well-suited to the needs of a new country - a scientific methodology based on structural linguistics and modern psychological theory which replaced the literary and cultural trimmings so beloved of the Raj with a 'culturally neutral' stance in which 'skills' and 'habits' were the key notions. It became known as the 'S-O-S' (Structural Oral Situational) method, a label which announced its close links with the Palmer-Hornby tradition. However, in an Indian context its teaching techniques were largely unfamiliar and required a considerable amount of in-service training before the approach could really get off the ground. (Howard, 1984: 346)

Hardly could those in charge of the whole programme have imagined at the time of devising and implementing it that the three letters "S-O-S" were, unbeknownst to themselves, ironically destined to haunt them years later in the form of a desperate cry for help from their unsuspecting Indian victims vented through the famous Morse code distress signal with which those letters are more familiarly associated! Be that as it may, the initial feedback gathered at the completion of 
the mammoth project had apparently indicated that it was money well-spent. But then it didn't take all that long for a subsequently despatched fact-finding mission, sent to assess the enduring impact of the gigantic effort, to come to the sad conclusion that almost all of the locals who had come out of the crash course with flying colours had already reverted back to their familiar way of speaking the language. Neither did it take very long for the Press in India to smell a rat and start digging into the whole episode to unearth some newsworthy dirt. The story soon hit the headlines in the leading newspapers in India and, as the repercussions gained extraordinary decibels, the Government of India took up the matter and appointed a one-man commission to submit a report (the usual delaying tactic).

And, as coincidence would have it, the person who was asked to do the job was none other than a professor of Linguistics by name Prabodh Bechardas Pandit who headed the Department of Linguistics at Delhi University where I happened to have concluded my master's degree just the year before. Whereof Dr. Brown's interest in taking me into her confidence, as I figured out in retrospect. To make matters once again so very coincidental, just before submitting his highly confidential report to the Ministry, Prof. Pandit had asked me for a personal favour of proof-reading the final version after making me swear to keep the whole thing under wraps (the report was only made public much later by the Government of India, that too in a heavily redacted version!). After all these years, all I can say is that it was somewhat jaw-dropping in its devastating condemnation of what he described as callous bungling on the part of everyone involved. Needless to say, when the Edinburgh don I referred to above spoke to me off the record, I had no choice but to pretend that I knew nothing about it, except what everyone else did through extensive newspaper coverage of the episode.

\section{Applied Linguistics and its dilemmas and occasional mess- ups}

After all these years, I would venture to say that if there is any significant takeaway from the debacle detailed above, it is, I think, the important lesson that just because something is done in the name of Applied Linguistics it doesn't mean that its results are automatically 
guaranteed and, more importantly, are squarely in the interests of those in whose benefit the steps in question were (or supposed to have been) taken. The programme of intervention that later came to be known as the 'Madras snowball' is an excellent case of the validity of the aphorism that says 'The road to hell is paved with good intentions.'

It is also a telling case in point as to how not to do applied linguistics. On closer inspection, it is not all that difficult to see that here we have a clear case of 'linguistics applied' (instead of 'applied linguistics') and the well-advisedness of Widdowson's (2001) timely warnings against the former. Let me explain. To begin with, let me make it clear right away that I will not chastise the brains behind the 'Madras snowball' disaster of having sought to advance a secret agenda of neo-colonial ramifications, although that was precisely what it was accused of by the report of the one-man commission I referred to earlier. Armed with hindsight, I would prefer to take a different tack.

The planners behind that elaborate programme were acting upon the prevailing wisdom of the day-grounded on 'solid', widely accepted consensus emerging from Linguistics that language, any language, belongs to its 'native speakers' and no one else besides. If one wanted to learn a language other than one's own, one had better ape a native speaker of that language. In Britain at that time, there was the additional tacit assumption that English truly and primarily belonged to the English (the very name clinches the issue, for God's sake!) and to no one else, even if they laid claims to being its native speakers 'of sorts'-Americans, Aussies, Kiwis ... well, you name them! (As clearly evidenced by my earlier account of the entrance exam of English language proficiency at Edinburgh University in the early 1970s).

If, barely a few decades after their country gained its independence, Indians were speaking the language in a way that sounded atrocious to the English ears, the diagnosis could only be that lack of daily contact with the native speakers of the language was the culprit. So there could conceivably be only one remedy: let them get some language infusion 'straight from the horse's mouth'! That already respectable branch of Linguistics called Phonetics and Phonology could lend them a helping hand. What other excellent example can one think of, of 
scientific knowledge already accumulated by academia - in this case, Linguistics - being put at the service of those in need of it?

\section{An unexpected taste of forensic linguistics}

My brief sojourn in Edinburgh in the early 1970s was also marked by a chance dabbling on my part in what I only years later realised as having been an exercise in forensic science, albeit on the margins. It all started with a casual encounter with the then distinguished Edinburgh professor of linguistics by name Ron(ald) Asher, a widely-acclaimed Dravidianist, who got interested in me when I told him that I was born in the state of Kerala, in India, where the language most widely spoken is Malayalam. He promptly took me aside and whispered to me asking if I would be willing to take on an assignment from-well, take a deep breath - the Scotland Yard, an invitation that, not surprisingly, came with an obligation to take an oath of secrecy. I confess I was flabbergasted by the offer, as the last thing I had expected to try my hand at in the land of Sherlock Holmes was the job of a sleuth.

Luckily it turned out that my job was a lot less risky than I had initially feared. It consisting in providing three separate levels of interpretation for messages scrawled on tattered pieces of scrap paper intercepted and taken possession of by the Agency: a verbatim translation, a possible gloss, and a freewheeling interpretation as to what I thought regarding what the sender of the message was trying to communicate. I enjoyed being part of an effort to break into a smuggling racket orchestrated from India and was glad to receive the handsome payoff (a nice shot in the arm!). I recount this story if only to make the point that hardly did I know at that time that forensic linguistics was, in matter of, say, three decades, to become a key part of applied linguistics, especially in Great Britain. As Roger Shuy's was to declare years later,

Forensic linguistics is an integral part of applied linguistics. Those who do this work analyze statutes, legal procedures, courtroom language, and language used as evidence in criminal and civil court cases. One major difference from other types of applied linguistics is that there is no need to gather data because it is already provided. (Shuy, 2011: 83) 


\section{Charting the course of an academic discipline from the point of view of so-called 'sociology of knowledge'}

I have long been convinced that disciplinary histories only make full sense when told from the vantage point of view what is referred as the 'sociology of knowledge'. Sociology of Knowledge presents a picture of the emergence of academic disciplines, not by invoking paradigm-internal factors (as typically done in the more familiar 'epistemology of sciences'). Rather, it pays attention to the historical circumstances that attend on the birth and growth of the new scientific enterprise, including odd facts that traditional philosophy of science would consider totally irrelevant or only of marginal interest (and, as it goes without saying, this also includes anecdotes and other tidbits of the kind exemplified in the foregoing section).

\section{LAEL and the historical setting of its emergence in the early 1970s}

\section{Some teething problems and early hiccups}

LAEL was set up in 1970 as the very first of its kind in the whole country and was almost instantly recognised as a centre of academic excellence (cf.: https://www.pucsp.br/pos-graduacao/mestrado-edoutorado/linguistica-aplicada-e-estudos-da-linguagem\#historia). The doctoral programme was inaugurated a decade later. The present writer, who had then recently arrived from his home country, India, (and had left behind him unfinished some initial spadework in what would have grown into a thesis in the field of sociolinguistics), was among those who formed the first batch of students - it is probably no exaggeration to say that we were some sort of 'guinea pigs' in a new doctoral programme that was still trying to figure out the right way of going about things.

In my own case, the description 'guinea pig' had an added appositeness if only for the strange coincidence that the Portuguese word for that laboratory animal is "porquinho-da-índia" (as I am told, Porcellino d'India in Italian and Cochon d'Inde in French)! So here 
was an Indian-'straight from the rickshaw,' as the late Prof. John Robert Schmitz, then a member of the teaching staff of LAEL and later my bosom friend and colleague at the State University at Campinas (UNICAMP), was fond of reminding me good-humouredly.

Anyway, we were a mixed bag, mostly made up of students who also had teaching jobs at the same Catholic University of São Paulo. We came from different areas of academia - departments of Portuguese, Linguistics and English. All that we had in common was plenty of excitement and a vague curiosity as to what awaited us down the line.

Not everything was plain-sailing in the beginning, though. Looking back on those days, it strikes me that not even the teaching staffnotably, Maria Antonieta Alba Celani, Mary Kato, Leila Barbara, John Robert Schmitz-were quite sure, I think, as to how they would go about things. Of all the four names mentioned, only the first, Celani, actually had more than an inkling of what applied linguistics was really all about or, for that matter, what the challenge before them actually amounted to. The others were trained in hard-core Linguistics and/or the teaching of English.

And, to be sure, the courses that were on offer all had to do with hard-core linguistics. Plenty of heavy duty syntax of Chomskyan provenance (the new kid on the block in Brazil in those days), some cutting-edge theories of language acquisition, some sociolinguistics (mostly quantitative-its qualitative rival was still in its nappies), some semantics (mostly lexical and truth-conditional) - well that was just about it. It is significant here to note that LAEL was by no means alone in groping around for meaningful course content, one that would set it apart from run-of-the-mill courses in Linguistics. The programme at Edinburgh University that I had gone through was pretty much similar (Pit Corder taught a discipline on TG syntax, mostly extolling the virtues of the new paradigm against the by-now discredited old, structuralist ones), Henry Widdowson (himself still working on his Ph.D. dissertation then) took care of sociolinguistics. Perhaps, the one discipline that stood out from the rest was the one on language testing (mostly statistics and arid number crunching, with an exaggerated dose of a certain Pilliner's-incidentally, himself an 
Edinburgh don - theorem - to me, an extremely abstruse educational testing method with mindboggling formulas and what have you ${ }^{2}$ )

\section{Steadying the ship after it had set sail and was already going full steam ahead}

Back to LAEL and its early meanders, then. For reasons that probably had to with the composition of its early teaching staff, the programme drifted along in its early years, torn between a strong commitment to hard-core linguistic theorising and a separate 'applied component' with a strong pedagogic orientation. But the grain remained stubbornly separated from the chaff and it strikes me that the programme often actually promoted the winnowing (without meaning to, as I would like to believe). I confess today that my own doctoral thesis which I finished in 1982 had precious little to with anything that would even remotely strike anyone as having anything to with applied linguistics.

The way I see it today, Applied Linguistics has more to do with a question of commitment and one's overall demeanour, a way of looking at the world at large, the society around one, and one's role in it and station in life than this or that specific orientation or thematic content. To be sure, it transcends language. It has to do, I think, with the researcher's own self much more than rules and maxims stipulated for the academic playing ground in which one has chosen to play.

2. I can still vividly remember what I only later perceived to have been a 'but-the-emperor-is-naked' sort of question (totally unintended, I swear) I asked Dr. Alan Davies, my course tutor, during a tutorial session immediately after a talk by Dr. Pilliner himself to a baffled audience of would-be applied linguists, mainly language teachers. After no one else had volunteered to ask a question by way of clarifying outstanding issues (we were all so dumbfounded!), I raised my hand and queried about a formula that contained the 'to-me-mystical' expression “ ' $n$ ' minus 1 ." "Why 'n' minus 1' and not, say, “ 'n' minus 2'?," I asked, much to the amusement of some of my class fellows sitting around in the crowded office room, adding "What is the big deal about the number 1 ?" The answer that was offered turned out to be even more intriguing. "Why "n minus 1 ... why not $n$ minus 2 ....," Alan kept repeating that like a mantra for some time, before coming up with this: "You know what? I honestly don't know why ...". Then, after a few more seconds of loud silence, he continued with something of a wry smile that only betrayed clear embarrassment at having been caught with his trousers down: "Maybe your unease with it has to do with the fact of your Indian upbringing." I thanked him, ignoring the ad hominem dig implicit in that response. 
That's why I believe that an applied linguist can ill afford to pass over in silence the twists and turns of their own personal biographies, the shaping of their own identities - who they are and where they speak from and the like - that, in hard sciences, we are constantly exhorted to relegate to the margins.

Predictably, the contrast with hard-core linguistic theorizing couldn't be any starker here. Consider the following confident assertion, made in the halcyon days of what was then widely hailed as the "queen of the social sciences' about what makes Linguistics so very scientific in the authors' view:

The facts of linguistic science in 1935 may be different from the facts of linguistic science in 1960, which in turn may be different from the facts of linguistic science in 1980. But what remain essentially unchanged and continually productive are the process of inquiry that we define as linguistics or, if you will, the linguistic enterprise. (Postman and Weingartner, 1966: 5)

If I may be pardoned for a rather lengthy quote from a paper I wrote more than a decade and half ago, here is how I continue to view such pompous drumbeats:

In other words, part of what is meant when its practitioners call linguistics a science is that the kind of knowledge it produces is timeless. Furthermore, it is believed to be equally well applicable to all cases, no matter how geographically or culturally diverse they may happen to be from one another. Notice, incidentally, that the authors of the passage cited above make no reference to dates earlier than 1935 . This is by no means fortuitous, because the science of modern linguistics is also anxious to deny its own historicity (Ehlich, 1981: 154).

\section{The secret of LAEL's vitality: a tribute}

All academic disciplines have skeletons in their cupboards. Anyone who denies it is just lying, plain and simple! Many thought in the early 20th century that anthropology was just another name for the insatiable appetite of some academics and those promoting their vested interests to look for hidden treasures in far-off lands and loot them! And anthropology was quite understandably the object of widespread public distrust. As recently as 2013, a mostly nondescript local newspaper in 
the US carried a guest column entitled 'Anthropologists should do a better job of promoting their field,' where the author unceremoniously chastised anthropology noting

Last August, Kiplinger named anthropology "the worst major for your career." Two months later, Forbes ranked "anthropology and archaeology," as No. 1 on its list of "worst college majors." (Ty Matejowsky and Beatriz M. Reyes-Foster, 2013)

However, the simple fact of their having harboured those skeletons in the past (or being accused of having done so) should not stand in the way we judge those disciplines today, the way the newspaper piece seems to be doing. After all, academic disciplines, like those who pursue and cultivate them, are constantly being subjected to the topics and thinkings (including outright prejudices) trending during the time-period under consideration. This only shows how delusional claims such as the one made above by Postman and Weingartner about the putative timelessness of scientific 'facts' reveal themselves to be. Academic disciplines must rather be judged by their readiness to embrace changing outlooks and ethical considerations and, even more importantly, the willingness to critically reassess their own conduct with a view to keeping themselves abreast of the times.

On this count, nobody can fault LAEL as it reaches its $50^{\text {th }}$ anniversary. It has not only borne witness, every step of the way, to the frequently changing spirit of the times, responding critically to its interdisciplinary, transdisciplinary and, why not, INdisciplinary phases, while refraining from jumping on the bandwagon merely for the sake of the dernier cri. Changes in orientation and priorities often come in fits and starts and LAEL is no exception to that rule. In this it simply follows a pattern clearly noticeable in every other major centre of applied linguistics all over the world.

Let me wrap up this piece saying: Kudos to my alma mater and all those who made this dream-LAEL-come true!

\section{Acknowledgement}

I am grateful to the $\mathrm{CNPq}$ for awarding me the research grant no. 300991/2019-3. 


\section{References}

BAYNHAM, Mike; DEIGNAN, Alice and WHITE, Goodith (eds.). 2004. Applied Linguistics at the Interface. London, UK and Oakville, USA: Association for Applied Linguistics in association with Equinox.

CORDER, S. Pit. 1973. Introducing Applied Linguistics. Harmondsworth: Penguin.

HARRIS, Zellig S. 1946. 'From Morpheme to Utterance'. Language. Vol. 22. No. 3. pp. 161-183.

. 1955. 'From Phoneme to Morpheme'. Language. Vol. 31. No. 2. 1955), pp. 190-222.

HOWATT, Anthony P. R. 1984. A History of English Language Teaching. Oxford: Oxford University Press.

LYONS, John. 1970. Chomsky. London: Fontana.

MATEJOWSKY, Ty and REYES-FOSTER, Beatriz M. 2013. 'Guest column: Anthropologists should do a better job of promoting their field.' Orlando Sentinel. April 24, 2013. https://www.orlandosentinel. com/opinion/os-xpm-2013-04-24-os-ed-anthropology-badreputation-042413-20130423-story.html,

PHILLIPSON, Robert. 1992. Linguistic Imperialism. Oxford, UK: Oxford University Press.

POSTMAN, Neil and WEINGARTNER, Charles. 1966. Linguistics: A Revolution in Teaching. New York: Dell Publishing Co. Inc.

RAJAGOPALAN, Kanavillil. 2003. 'The philosophy of applied linguistics.' In: Davies, Alan e Elder, Catherine (eds.) Handbook of Applied Linguistics. New York: Blackwell Publishers. pp. 397-420. 2005. 'The language issue in Brazil: when local knowledge clashes with expert knowledge.' In: Canagarajah, A. Suresh (ed.). Reclaiming the Local in Language Policy and Practice. New Jersey, Mahwah: Lawrence Erlbaum Associates, publishers. pp. 99-121.

SHUY, Roger W. 2011. 'Applied linguistics and the legal arena.' In: Candlin, Christopher N. and Sarangi, Srikant (eds.) Handbook of Communication in Organisations and Professions. pp. 83-102.

VAN LIER, Leo. 1994. 'Educational linguistics: field and project.' In: Alatis, James E. (ed.). Georgetown University Round Table on Language and Linguistics. Washington, D.C.: Georgetown University Press. pp. 32-59.

WIDDOWSON, Henry. 2001. 'On the limitations of linguistics applied.' Applied Linguistics. 21: 1. pp. 3-25. 